ARCHIWUM FILOZOFII PRAWA

I FILOZOFII SPOŁECZNEJ

2019/1

Maksymilian Hau', Stanisław Jędrczak ${ }^{2}$

Uniwersytet Warszawski

\title{
Prawo - osoba - śmierć. Część II: Teoria Daniela Sperlinga a polski system prawny
}

\section{Uwagi wstępne}

W artykule pt. Prawo - osoba - wolność. Część I: Wokót koncepcji Daniela Sperlinga ${ }^{3}$ przedstawiliśmy filozoficzną koncepcję interesów pośmiertnych, ze szczególnym uwzględnieniem teorii podmiotu ludzkiego (ang. Human Subject) sformułowanej przez Daniela Sperlinga. Nawiązując do tej koncepcji rozważamy w niniejszym artykule możliwość zastosowania teorii D. Sperlinga w polskim systemie prawnym. Należy podkreślić, że teoria D. Sperlinga dotyczy anglosaskiego reżimu prawnego. W związku z tym, że decydującą rolę odgrywają w nim prawotwórcze orzeczenia sędziów, D. Sperling dużą część badań poświęca analizie wyroków stanowiących silną inspirację dla jego teorii ${ }^{4}$. Technika legislacyjna nie stwarza przeszkód przed skonstruowaniem pojęcia podmiotu ludzkiego w kontynentalnych systemach prawnych. Najpierw należy się jednak zastanowić, które, spośród już istniejących instytucji, są lub mogą być wykorzystane do ochrony interesów zmarłych, a następnie raz jeszcze zadać pytanie o użyteczność pojęcia podmiotu ludzkiego.

Według D. Sperlinga interesy post mortem są chronione w przynajmniej dwóch obszarach prawa: prawie autorskim osobistym i prawie medycznym regulującym kwestię prywatności pacjenta ${ }^{5}$. W polskiej doktrynie podstawę dla takich rozważań stanowią również prawo autorskie osobiste oraz prawo ochrony dóbr osobistych, dokładnie: prawo do ochrony kultu i pamięci po osobie zmarłej. W artykule omówimy także zagadnienie statusu danych medycznych po śmierci pacjenta i pośmiertnego przyznawania lub odbierania odznaczeń oraz spróbujemy rozstrzygnąć, czy koncepcja D. Sperlinga znajduje zastosowanie w polskim ustawodawstwie.

Numer ORCID: 0000-0003-2457-6445. Adres e-mail: maks.hau@me.com

Numer ORCID: 0000-0002-4814-2409. Adres e-mail: stanislaw.jedrczak@gmail.com

3 M. Hau, S. Jędrczak, Prawo - osoba - śmierć. Część I: Wokót koncepcji Daniela Sperlinga, „Archiwum Filozofii Prawa i Filozofii Społecznej” 2018/2, s. 75-89.

4 D. Sperling powołuje się na ok. 250 różnych orzeczeń z krajów anglosaskich. Dwa duże rozdziały, z pięciu w całej książce, są poświęcone prawie w całości ich analizie. Por. D. Sperling, Posthumous Interests, Cambridge 2008, rozdz. pt. Proprietary interests in the body of the deceased i Determining the disposal of the one's body after death.

D. Sperling, Posthumous..., s. 46-47. 
Polska doktryna sprzeciwia się stanowczo uwzględnieniu interesów osób już nieżyjących jako praw podmiotowych ${ }^{6}$. Przeciwko nim wysuwany jest zazwyczaj zarzut nieistnienia ich podmiotu. Przypomnijmy, że ochrona prawna jednostki w prawie cywilnym opiera się na koncepcji dóbr osobistych, czyli szczególnie istotnych interesów ${ }^{7}$. Chronią je prawa podmiotowe. Podmiotem tych praw (przy dobrach osobistych zwraca uwage szczególna siła tej relacji) jest osoba fizyczna - definiowana jako żywy człowiek ${ }^{8}$. Warto podkreślić, że ustawodawca nie stwarza interesów, w tym dóbr osobistych, a jedynie uznaje, że niektórym z nich należy się ochrona prawna.

Kodeksowe rozumienie osoby fizycznej jest wąskie. Osoba fizyczna to człowiek, który urodził się żywy ${ }^{9}$. Nie obejmuje ono jednak człowieka w każdej epoce jego życia, a także osób już nieżyjących. Mamy tym samym do czynienia z sytuacją, w której uznane interesy jednostki nie są prawnie chronione. Dlaczego więc pojęcie podmiotu jest w prawie cywilnym definiowane tak wąsko? Warto w tym miejscu przytoczyć spostrzeżenie Romana Longchamps de Beriera: podmiotowość prawna nie jest rozumiana substancjalnie, ale normatywnie. Podmiot spełniający określone normatywnie warunki stanowi podmiot prawa ${ }^{10}$.

R. Longchamps de Berier podaje trzy warunki, które musi spełnić podmiot, by stać się podmiotem praw ${ }^{11}: 1$ ) musi posiadać interesy i być zdolnym do ich realizacji; 2) musi posiadać zdolność do powzięcia woli sam albo przez przedstawiciela; nie jest przy tym wymagane, by podmiot posiadał pewne stany mentalne, ponieważ zastępca działa realizując jego obiektywny interes; 3 ) musi być członkiem społeczności ludzkiej, ponieważ prawo obowiązuje w społeczeństwie. Czy elementy te wyłączają możliwość uwzględnienia interesów zmarłych? Osoby zmarłe mają interesy, mogą być one wszakże realizowane jedynie przez ich przedstawicieli. Za Johnem Perrym przekonywaliśmy jednak, że pierwszoosobowa realizacja interesu jest derywatywna wobec jego obiektywnej realizacji. Zdolność do niej nie stanowi zatem warunku koniecznego posiadania interesu. Przez wspólnotę ludzką R. Longchamps de Berier rozumie wspólnotę interesów, której żywy człowiek jest pierwotnym i samoistnym przedstawicielem ${ }^{12}$. Inne podmioty, takie jak osoby prawne, zostają do niej włączone na mocy decyzji. Takie rozumienie społeczności ludzkiej nie wyklucza z niej osób zmarłych. Wielość instytucji prawnych mających za cel zabezpieczenie przyszłych (np. dzięki testamentowi) oraz przeszłych (zob. analizowane poniżej przykłady) interesów dowodzi, że do wspólnoty interesów należą nie tylko osoby istniejące aktualnie. Ograniczenie wspólnoty ludzkiej do żywych członków wydaje się arbitralne. Wybór ten może uzasadnić jedynie wskazanie prawnie relewantnej cechy przysługującej żywym w odróżnieniu od zmarłych. Cechy tej nie stanowi na pewno zdolność do bezpośredniej realizacji własnych interesów, które są realizowane przez zastępcę. Argumentuje się, że osoba już nieżyjąca nie może ponieść

\footnotetext{
${ }^{6}$ Odpowiedź podsekretarza stanu w Ministerstwie Sprawiedliwości Andrzeja Dudy - z upoważnienia ministra - na interpelację nr $8701 \mathrm{w}$ sprawie ochrony danych osobowych osób zmarłych, orka2.sejm.gov.pl/IZ5.nsf/ main/67FAE054, dostęp: 23.06.2017 r. Por. J. Mazurkiewicz, Non omnis moriar. Ochrona dóbr osobistych zmartego w prawie polskim, Wrocław 2010, s. 21 i wymieniane tam przykłady.

7 Co ważne, obecnie w ocenie wartości dobra osobistego dominuje teoria obiektywistyczna. Ponadto dobra osobiste nie mają jednej definicji, co podkreśla otwartość ich katalogu. Por. M. Pazdan, w: K. Pietrzykowski (red.), Kodeks cywilny. Tom I. Komentarz do artykutów 1-449, Warszawa 2008, s. 114.

M. Pazdan, w: K. Pietrzykowski, Kodeks cywilny..., s. 90.

9 Por. art. 8 ustawy z 23.04.1964 r. - Kodeks cywilny (tekst jedn.: Dz. U. z 2018 r. poz. 1025 ze zm.), dalej: „k.c.”.

10 R. Longchamps de Berier, Studya nad istota osoby prawniczej, Lwów 1911, s. 132-133.

11 R. Longchamps de Berier, Studya ..., s. 155-163.

12 R. Longchamps de Berier, Studya..., s. 162
} 
krzywdy; przedstawiliśmy jednak wystarczające racje na rzecz przeciwnego stanowiska. Również argumenty funkcjonalne głoszące, że zrównanie ochrony interesów osób żyjących i zmarłych sparaliżowałaby system prawny, nie są przekonywające. Ochrona zmarłych ma z konieczności węższy zakres; dotyczy jedynie niektórych dóbr osobistych. R. Longchamps de Berier odmawiał podmiotowości prawnej zmarłym, ponieważ nie dostrzegał ich interesów ${ }^{13}$; skoro zmarli, jak twierdzimy, posiadają interesy - stanowisko to traci uzasadnienie.

Zapytajmy następnie, czy prawa (podmiotowe) potrzebują podmiotu? Analizując historyczne koncepcje podmiotowości prawnej, R. Longchamps de Berier przywołuje stanowisko reprezentowane m.in. przez Bernharda Windscheida. Zgodnie z teorią fikcyjności przeczy się istnieniu osoby prawnej, wymagając zarazem realnego istnienia podmiotu praw ${ }^{14}$. Rozwiązaniem problemu miała być ich zdaniem konstrukcja „odpodmiotowionych" praw podmiotowych. Myśl tę rozwinął w odniesieniu do tytułowej tematyki Jacek Mazurkiewicz.

Autor ten zauważa, że w prawie polskim istnieją przepisy zapewniające ochronę post mortem $^{15}$. Według J. Mazurkiewicza problem podmiotu jest rozwiązany przez związanie interesów zmarłego z interesem osób, które istnieją aktualnie, nie zawsze z powodzeniem $^{16}$. Propozycja teoretyczna J. Mazurkiewicza opiera się na wspomnianych dobrach odpodmiotowionych. W jej myśl przedmiotem ochrony nie są interesy zmarłego ani dobra „osobiste” osoby, która kiedyś żyła, ale powstałe dobra osobiste, odpowiednio zastępującą dawne ${ }^{17}$. Obowiązek ochrony wynika stąd, że nowe dobra, wciąż osobiste, są wyrazem continuum osoby, która już nie istnieje. Continuum stanowi reprezentację osoby ante mortem, którą posługują się żyjący; co odpowiada D. Sperlinga koncepcji istnienia symbolicznego. Stan ten J. Mazurkiewicz określa pojęciem residuum. Znamienne są w tym ujęciu prawa autorskie; utwory, podobnie jak D. Sperling, J. Mazurkiewicz uważa za emanację osobowości autora ${ }^{18}$. Taki pogląd budzi pewne zastrzeżenia.

W koncepcji J. Mazurkiewicza niejasny jest powód, dla którego odmawia się istnienia interesów osób już nieżyjących, przyznając jednak istnienie dóbr osobistych. Uzasadnieniem ochrony jest możliwość naruszenia interesów osoby. J. Mazurkiewicz sugeruje więc, że w momencie śmierci przestajemy istnieć naturalnie, lecz istniejemy wciąż symbolicznie, i to nowe istnienie wymaga ochrony. Pogląd J. Mazurkiewcza odpowiada poglądowi D. Sperlinga - continuum i residuum są zbieżne treściowo z istnieniem symbolicznym. Przeczy to jednak przywołanej na początku koncepcji praw odpodmiotowionych, ponieważ zostaje tu wskazany podmiot ochrony. Ponadto jest on łatwy do konkretyzacji. Przykładowo analizowana przez J. Mazurkiewicza ustawa z 3.02.2001 r. o ochronie dziedzictwa Fryderyka Chopina ${ }^{19}$ chroni interesy Fryderyka Chopina. Także według koncepcji J. Mazurkiewicza i D. Sperlinga podmiotem ochrony jest osoba, chociaż pośrednio: identyfikowana dzięki swojej reprezentacji symbolicznej20.

13 R. Longchamps de Berier, Studya..., s. 153.

14 R. Longchamps de Berier, Studya..., s. 12.

15 Autor wymienia wiele dziedzin prawa, w tym przede wszystkim prawo autorskie, ale również prawo o aktach stanu cywilnego, prawo rodzinne, prawo prasowe.

16 Por. wyrok Sądu Najwyższego (dalej: „SN”) z 4.11.1969 r. (II CR 390/69), LEX nr 6606, gdzie SN orzekał w sprawie owdowiałego małżonka, który wbrew woli zmarłej, pochował ją pod swoim nazwiskiem, a nie panieńskim.

17 J. Mazurkiewicz, Non omnis..., s. 24. Oczywiście dobra osobiste, takie jak prawo do życia czy zdrowia, nie będą adekwatne.

18 J. Mazurkiewicz, Non omnis..., s. 31.

19 Dz. U. Nr 16, poz. 168.

20 Por. D. Sperling, Posthumous..., s. 39; J. Mazurkiewicz, Non omnis..., s. 718. 
2. Wyrażenie zgody na zabieg operacyjny, gdy pacjent nie decyduje samodzielnie, jako przykład możliwego sposobu funkcjonowania ochrony post mortem

D. Sperling sugeruje, że kwestia ochrony osób zmarłych odpowiada kwestii decydowania za pacjenta znajdującego się w stanie wyłączającym możliwość podjęcia samodzielnej decyzji ${ }^{21}$. Rozpatrzmy więc przypadek, gdy konieczne jest podjęcie decyzji o wyrażeniu zgody na zabieg operacyjny. Należy zastanowić się nad dwoma głównymi problemami: 1) kto ma podjąć decyzję, jeżeli pacjent nie jest w stanie wyrazić zgody?; 2) jakim kryterium należy się kierować przy podejmowaniu decyzji? Odpowiadając na pierwsze pytanie, powiemy że decydować ma osoba uprawniona. Fakt, że o dobrostanie jednej osoby może decydować inna, nie budzi kontrowersji. Osobą tą może być przedstawiciel prawny, opiekun faktyczny, lekarz, sąd rodzinny ${ }^{22}$. Odpowiedzi na drugie pytanie możemy udzielić, odwołując się do koncepcji angielsko-kanadyjskiej albo amerykańskiej²3. W pierwszym przypadku kryterium stanowi najlepszy interes ${ }^{24}$ pacjenta, który ma charakter czysto obiektywny. W drugim przypadku element subiektywny jest dowartościowany. Kryterium stanowi odpowiedź na pytanie: czy nieświadomy pacjent zgodziłby się na dany zabieg, gdyby mógł zdecydować sam? Kryterium pozwala na włączenie osobistych przekonań pacjenta, jego wcześniejszych życzeń i innych oświadczeń woli, które kiedyś przedkładał, w proces decyzyjny.

Polskie prawo medyczne skłania się ku pierwszej koncepcji. Świadczą o tym przypadki interwencji sądów rodzinnych w braku zgody np. rodzin świadków Jehowy na transfuzję krwi dziecka. Analogia ta pokazuje przede wszystkim, że prawo jest już wyposażone w mechanizmy ochrony interesów osób, które nie są w stanie wyrazić woli dotyczącej zmiany własnego dobrostanu. Ponadto w odpowiednich przepisach nie kwestionuje się istnienia interesów obiektywnych, które są chronione są przez uprawnione osoby trzecie.

\section{Prawa autorskie niemajątkowe jako przykład istniejących uregulowań post mortem}

Ustawa z 4.02.1994 r. o prawie autorskim i prawach pokrewnych ${ }^{25}$ wyróżnia autorskie prawa majątkowe i autorskie prawa osobiste. Pierwsze dają twórcy prawo do korzystania i rozporządzania utworem oraz do wynagrodzenia za korzystanie z utworu. Wygasają po 70 latach od śmierci twórcy i mogą zostać przekazane przez dziedziczenie albo na podstawie umowy. Autorskie prawa majątkowe nie mają charakteru post mortem, ponieważ od chwili śmierci twórcy korzyści związanie z prawem autorskim przysługują innym podmiotom. Zmarłemu nie przypisuje się interesów post mortem, a jedynie ante mortem, np. możliwość rozporządzenia prawami w testamencie. Drugi rodzaj praw autorskich, prawa osobiste, chronią więź twórcy z utworem. Należą do nich prawo do autorstwa utworu, oznaczenia go nazwiskiem lub pseudonimem autora, nienaruszalności utworu itp. Dla naszych rozważań istotne jest sformułowanie zawarte w art. 16 pr. aut., według którego wspomniana więź twórcy z autorem podlega ochronie nieograniczonej w czasie. W związku z tym przepisem pojawią się dwa pytania. Po pierwsze, czy

21 D. Sperling, Posthumous..., s. 2 i 71-72.

22 Por. art. 32-34 ustawy z 5.12.1996 r. o zawodach lekarza i lekarza dentysty (tekst jedn.: Dz. U. 2019 r. poz. 537). Warto w tym miejscu dodać, że w polskim prawie nie istnieje instytucja zgody rodziny na wykonanie zabiegu, por. M. Boratyńska, P. Konieczniak, Prawa pacjenta, Warszawa 2001, s. 240-241.

23 D. Sperling, Posthumous..., s. 71-72.

24 Mental Capacity Act 2005, s. 4, http://www.legislation.gov.uk/ukpga/2005/9/section/4, dostęp: 27.06.2017 r.

25 Tekst jedn.: Dz. U. z 2018 r. poz. 1191 ze zm., dalej: „pr. aut.”. 
rzeczywiście autorskie prawa osobiste mogą przetrwać twórcę? Po drugie, czy wyrażenie nieograniczone $w$ czasie wyznacza ramy czasowe?

Na pierwsze pytanie doktryna udzieliła dwóch przeciwstawnych odpowiedzi. Reprezentanci doktryny francuskiej ${ }^{26}$ uważają, że dobra osobiste autora trwają bezterminowo ${ }^{27}$, a śmierć nie skutkuje ich zmianą. W tym duchu sformułowany jest art. $6^{\text {bis }}$ ust. 2 zdanie pierwsze Aktu paryskiego konwencji berlińskiej o ochronie dzieł literackich i artystycznych ${ }^{28}$, w myśl którego: „Prawa przyznane autorowi na podstawie ustępu 1 pozostają w mocy po śmierci autora co najmniej do czasu wygaśnięcia praw majątkowych i są wykonywane przez osoby lub instytucje upoważnione do tego przez ustawodawstwo wewnętrzne państwa, w którym żąda się ochrony". Kto jest podmiotem chronionych interesów? Fryderyk Zoll w trójdzielnej konstrukcji droit moral proponuje rozwiązanie podobne do tego, jakie reprezentują Janusz Barta i Ryszard Markiewicz ${ }^{29}$. Otóż w chwili śmierci więź podmiotu (autora) z przedmiotem (utworem) ulega rozerwaniu, a miejsce autora zastępuje inny podmiot - ogólny (społeczny) dorobek kulturalny według J. Barty i R. Markiewicza albo prawo publiczne przysługujące społeczeństwu do przeciwdziałania czynom zniekształcającym dzieło bądź wprowadzającym w błąd co do autorstwa w ujęciu F. Zolla. Pogląd taki nie wydaje się wystarczający. Nie chroni bowiem interesów zmarłego twórcy, który może zostać skrzywdzony, lecz w zamian proponuje ochronę (trudno definiowalnego) interesu ogółu. Bliższą naszemu stanowisku koncepcję proponuje J. Mazurkiewicz, według którego pośmiertnej ochronie podlegają wciąż dobra osobiste odpodmiotowione, a zastępca, czy inny strażnik tych dóbr, nie realizuje własnych interesów (jako przedstawicieli społeczeństwa), ale broni dóbr zmarłego. Przedstawiciele doktryny nie mówią jednak o interesie twórcy dzieła, który już nie żyje, a którego interesom należy zagwarantować ochronę prawną.

Zwolennicy teorii wygaśnięcia praw osobistych twórcy wraz z jego śmiercią ponawiają zarzut braku podmiotu dla praw autorskich. Trzeba dodać, że nie analizują oni możliwości naruszenia interesu zmarłego. W związku z tym wydaje się, że nie odróżniają podmiotu interesów od samych interesów. Według tych autorów ${ }^{30} \mathrm{w}$ momencie śmierci związek podmiotu i przedmiotu praw autorskich ulega utożsamieniu, a ochrona tego stanu jest w interesie społecznym. Powraca więc wspomniany już problem: czy tym samym ustawodawca dąży do ochrony interesu ogółu?

Drugie pytanie dotyczy tego, jak długo powinniśmy udzielać ochrony prawnej osobistym prawom autorskim. Wspomniana Konwencja berlińska proponuje okres równy przynajmniej okresowi ochrony majątkowych praw autorskich. Krzysztof Czub uwa$\dot{z} a$, że czas ten powinien odpowiadać czasowi istnienia utworów w obrocie prawnym ${ }^{31}$. D. Sperling odpowiedziałby, że dopóki trwa pamięć o dziele (możliwość identyfikowania podmiotu ludzkiego z autorem, który już nie żyje), a J. Mazurkiewicz - dopóki istnieje

26 Prawo francuskie również w innych obszarach zawiera uregulowania post mortem; por. zawieranie małżeństw z poległymi żołnierzami wspominane przez J. Mazurkiewicza. Zob. J. Mazurkiewicz, Czy dobra osobiste moga powstać po śmierci?, w: J. Balcarczyk (red.), Dobra osobiste w XXI wieku. Nowe wartości, zasady, technologie, Warszawa 2012, s. 426.

27 K. Czub, Dobra i prawa osobiste twórcy (na podstawie kodeksu cywilnego, prawa autorskiego i prawa własności przemystowej), w: J. Gołaczyński et al. (red.), Non omnis moriar. Osobiste i majątkowe aspekty prawne śmierci człowieka. Zagadnienia wybrane, Wrocław 2015, s. 136.

28 Dz. U. z 1990 r. Nr 82, poz. 474.

29 K. Czub, Dobra..., s. 137-138.

30 K. Czub wymienia tu Stefana Grzybowskiego, Wiktora Serdę, Elżbietę Wojnicką.

31 K. Czub, Dobra ..., s. 144. 
dzieło, czyli być może bezkreśnie ${ }^{32}$. Odpowiedź J. Mazurkiewicza współgra z odpowiedzią D. Sperlinga. Moment odkrycia dzieła jest Sperlingowską aktualizacją istnienia symbolicznego przez przywołanie twórcy w pamięci żyjących. Oba stanowiska wyrażają pogląd, że ochronie nie wyznacza się abstrakcyjnie końca na osi czasu (jak też samej epoce farlife-longing interests D. Sperlinga). Ochrona powinna być udzielona zawsze, gdy interes podmiotu może być naruszony. Upływ czasu, a zwłaszcza narastająca wartość historyczna, może być argumentem, by osłabić ochronę in concreto, ale nie świadczy za jej całkowitym pozbawieniem (np. w kwestii pochówku).

\section{Ochrona kultu pamięci o osobie zmarłej a ochrona interesów osoby nieżyjącej}

Dobro osobiste, jakim jest prawo do kultu pamięci o osobie zmarłej, funkcjonuje w polskim systemie prawnym jako surogat ochrony interesów osób już nieżyjących. Zabezpieczyć może jedynie interesy, które dają się łączyć z interesami osób żyjących. To główny zarzut stawiany ochronie interesów zmarłych przez kult pamięci. Krąg podmiotów mogących występować w ich obronie jest ograniczony. Kodeks cywilny nie wymienia ich, ale orzecznictwo i doktryna przywołują w tym kontekście uprawnionych do pochowania zmarłego, wymienionych w art. 10 ustawy z 31.01.1959 r. o cmentarzach i chowaniu zmarłych ${ }^{33}$. Są nimi najbliżsi zmarłego. Wynikają stąd istotne ograniczenia ochrony wielu podmiotów. Nie udziela się jej osobie, która nie ma bliskich. Także interesy bliskich mogą pozostawać w sprzeczności z interesami osoby zmarłej. Wreszcie bliscy mogą nie być zainteresowani dbaniem o interesy osoby już nieżyjącej. Analiza orzecznictwa dokonana przez J. Mazurkiewicza wykazuje, że podstawą ochrony kultu pamięci jest intuicja, zgodnie z którą należy udzielać jakiejś ochrony zmarłym ${ }^{34}$.

Owa quasi-ochrona za pośrednictwem kultu pamięci jest, z wymienionych już powodów, narzędziem nieskutecznym. Ponadto nie pozwala na osiągnięcie zamierzonego celu. Kult pamięci ma służyć jedynie żywym, chroniąc ich interesy związane pamięcią o zmarłych. Zakres tej ochrony może, ale nie musi, pokrywać się z zakresem ochrony pośmiertnej. Różnica leży w celu. Kult pamięci służy ochronie uczućc35, podczas gdy proponowana ochrona interesów post mortem opiera się na obiektywnym kryterium krzywdy. Krzywdy wyrządzonej osobie nieżyjącej, nie bliskiemu, który jeszcze żyje albo wyrządzonej zaledwie pośrednio i ze względu na żyjących ${ }^{36}$.

\section{Ochrona danych osobowych osoby zmarłej}

D. Sperling podkreśla, że istotnym obszarem prawa, w którym działają przepisy post mortem, jest ochrona danych osobowych pacjenta ${ }^{37}$. To szerokie pole możliwych naruszeń interesów zmarłego. Dane dotyczące zdrowia mogą zostać wykorzystane przez korporacje medyczne, także ujawnienie przyczyny śmierci narusza niekiedy interesy

\footnotetext{
32 Według J. Mazurkiewicza czas, w którym nikt nie pamiętałby o twórcy albo dziele, to momenty „zakrycia” dzieła. Wystarczy jednak, że zostanie ono odkryte, a ochrona powinna dalej trwać. Ustanie tylko w momencie zniszczenia dzieła. Por. J. Mazurkiewicz, Non omnis..., s. 784.

33 Tekst jedn.: Dz. U. z 2017 r. poz. 912. Por. T. Gardocka, Czy zwtoki ludzkie sq̨ rzeczq i co z tego wynika?, w: J. Gołaczyński et al. (red.), Non omnis..., s. 268.

34 J. Mazurkiewicz, Non omnis..., s. 58-59 i przywoływane tam orzeczenia.

35 Zob. W. Dubois, M. Daćków, Prawo do bycia zapomnianym w internecie - za życia i po śmierci?, w: J. Gołaczyński et al. (red.), Non omnis..., s. 184-185.

36 Por. J. Mazurkiewicz, Non omnis..., s. 62-63.

37 D. Sperling, Posthumous..., s. 190-192.
} 
zmarłego - zwłaszcza jeżeli np. zmarł na AIDS czy popełnił samobójstwo ${ }^{38}$; zdarzało się, że dane te posłużyły w pewnych przypadkach do folgowania osobliwym przyjemnościom $^{39}$. Poszanowanie tajemnicy medycznej jest zagwarantowane w prawie międzynarodowym $^{40}$, a art. 4 ust. 1 Deklaracji w sprawie promowania praw pacjenta w Europie ${ }^{41}$ gwarantuje je również po śmierci. Artykuł 24 ust. 3 ustawy z 6.11.2008 r. o prawach pacjenta i Rzeczniku Praw Pacjenta ${ }^{42}$ zobowiązuje administratorów danych medycznych do zachowania tajemnicy także po śmierci pacjenta. Artykuł 26 ust. 2 powyższej ustawy w brzmieniu sprzed nowelizacji uzależniał dostęp do dokumentacji medycznej od udzielenia przez pacjenta zgody za życia. Warto dodać, że w orzeczeniu Naczelnego Sądu Administracyjnego (dalej: „NSA”) uznano możliwość dostępu do danych medycznych przechowywanych przez placówkę inną niż ta, której udzielono zgody ${ }^{43}$. Czy taka konstrukcja przepisów zapewniała ochronę interesów pacjenta? Zabezpieczone z pewnością były interesy osoby już nieżyjącej, gdyż zagwarantowano niepublikowanie informacji, których za życia nie chciała ona ujawnić. Z drugiej strony, krytykowano trudności powstające, gdy pacjent umiera niespodziewanie, zanim zdecyduje o upoważnieniu do udzielenia informacji. Problem ten można było rozwiązać chociażby przez wprowadzenie czasowej ważności takiej zgody (zawsze możliwej do odwołania). Nowelizacja art. 26 ust. 2 omawianej ustawy częściowo odpowiada na te potrzeby. Obecnie dokumentacja medyczna może zostać pośmiertnie udostępniona także osobie, która w chwili zgonu była przedstawicielem ustawowym pacjenta oraz osobie bliskiej, chyba że sprzeciwił się temu sam pacjent za życia lub inna osoba bliska. Należy zaaprobować ostatnie działania ustawodawcy w tym zakresie, ponieważ stanowią rozsądny kompromis między ochroną interesów zmarłego w zakresie prywatności a koniecznością umożliwienia podjęcia postępowania odszkodowawczego (ujawniona dokumentacja medyczna może wykazać ewentualne nieprawidłowości, które będą stanowić podstawę roszczeń). Należy jednak mieć na uwadze, że w tym przypadku zawsze dochodzi do konfliktu dóbr, w którym mniej oczywiste dobro podlega silniejszej ochronie, ale ostatecznie decyzja należy do zainteresowanego.

Niekiedy proponowana jest zmiana w brzmieniu wspomnianych przepisów, wprowadzająca domniemaną zgodę na udzielenie pośmiertnej informacji medycznej małżonkowi. Oceniamy ją negatywnie. Przypomnijmy odnotowaną wcześniej uwagę, że interesy osób najbliższych nie zawsze zgadzają się z interesami osób już nieżyjących. Ponadto wiele osób nie jest świadomych, kiedy interesy te zostają naruszone. Za życia sam zainteresowany mógłby dochodzić np. usunięcia ujawnionej informacji, a w ramach obecnych regulacji byłoby to bardzo utrudnione.

Omawianą kwestię warto rozszerzyć poza prawo medyczne. D. Sperling wielokrotnie akcentuje wątłość albo brak ochrony danych osobowych zmarłych. Problematyka ta staje się wyraźna w odniesieniu do internetu. Usunięcie danych udostępnionych na portalach społecznościowych jest utrudnione. Podstawą prawną relacji użytkownika z takim portalem są umowy o warunkach świadczenia usług lub umowy licencyjne

\footnotetext{
38 Np. przez konieczność okazania pracodawcy aktu zgonu, w którym ujawniona jest przyczyna śmierci. Por. też fałszowanie tych danych opisywane przez D. Sperlinga, Posthumous..., s. 217.

39 D. Sperling opisuje sprawę Reid v. Pierce County, w której rodzina zmarłego pozwała pracowników hrabstwa za pokazywanie zdjęć z autopsji na przyjęciach. Por. D. Sperling, Posthumous..., s. 221.

40 Por. D. Sperling, Posthumous..., s. 189-190 i przywoływane tam akty prawne.

41 http://www.who.int/genomics/public/eu_declaration1994.pdf, dostęp: 23.06.2017 r.

42 Tekst jedn.: Dz. U. z 2017 r. poz. 1318 ze zm.

43 Wyrok NSA z 17.09.2013 r. (II OSK 1539/13), LEX nr 1396095.
} 
dla użytkownika końcowego ${ }^{44}$. W większości nie regulują one, co staje się z danymi po śmierci użytkownika. Powstaje więc luka prawna, ponieważ dane te są przechowywane na serwerach będących własnością właściciela danego serwisu. Siedziby serwisów zazwyczaj znajdują się w krajach anglosaskich, więc w zakresie ochrony danych osobowych normy umów licencyjnych pozostają w sprzeczności z wewnętrznymi normami państw. W Polsce art. 51 ust. 4 Konstytucji RP ${ }^{45}$ oraz art. 16 i 17 RODO $^{46}$ dają podstawy do żądania od dostawcy usług m.in. usunięcia informacji ${ }^{47}$. Ilość, jakość i ważność udostępnianych danych już jest bardzo duża i na pewno wzrośnie wraz ze zwiększeniem się możliwości technicznych portali ${ }^{48}$. Pojawia się tu problem bezpieczeństwa danych ze względu na podatność na cyberprzestępczość ${ }^{49}$. Obecnie jedynie z Facebooka korzystają prawie dwa miliardy aktywnych użytkowników ${ }^{50}$. Szacuje się, że co godzinę umiera 428 z nich ${ }^{51}$.

Po śmierci użytkownika jego profil pozostaje zazwyczaj bez zmian ${ }^{52}$. Stwarza to możliwość naruszenia jego interesów wskutek udostępnienia wrażliwych informacji. D. Sperling podkreśla ten argument, ponieważ rola internetu w podtrzymywaniu istnienia symbolicznego jest istotna ${ }^{53}$. Interesujący przykład naruszenia interesów podał Werner Herzog w filmie Lo $i$ stało się $e^{54}$ : rodzina kobiety, zmarłej w wypadku samochodowym wskutek dekapitacji, bezskutecznie domagała się zaprzestania rozpowszechniania na Facebooku zdjęć jej ciała. Współgrają tu interesy zarówno osoby już nieżyjącej w ochronie jej wizerunku, jak i rodziny - w prawie do ochrony kultu.

Polskie ustawodawstwo odmawia ochrony danych osobowych zmarłego ${ }^{55}$. Jest to interesujące, ponieważ z powodzeniem chronione jest prawo pacjenta do prywatności po śmierci. Następny problem wiąże się z niemożnością domagania się usunięcia danych prawdziwych, przetwarzanych zgodnie z ustawą, czyli też za udzieloną wcześniej zgodą użytkownika ${ }^{56}$.

Doktryna dostrzega omawiane kwestie, próbując jednak umieścić je w ramach ochrony kultu pamięci o osobie zmarłej ${ }^{57}$, co rodzi wskazane wcześniej problemy. Ciekawe

44 Wyrok NSA z 17.09.2013 r. (II OSK 1539/13).

45 Konstytucja Rzeczypospolitej Polskiej z 2.04.1997 r. (Dz. U. Nr 78, poz. 483 ze zm.).

46 Rozporządzenie Parlamentu Europejskiego i Rady (UE) 2016/679 z 27.04.2016 r. w sprawie ochrony osób fizycznych w związku z przetwarzaniem danych osobowych i w sprawie swobodnego przepływu takich danych oraz uchylenia dyrektywy 95/46/WE (ogólne rozporządzenie o ochronie danych) (Dz. Urz. UE L 119 z 4.05.2016 r., s. 1, dalej: „RODO”). Wejście w życie RODO wzmacnia uprawnienie do tzw. prawa do bycia zapomnianym, czyli żądania od administratora danych usunięcia posiadanych danych o użytkowniku. RODO zobowiązuje również do zaprzestania przetwarzania danych w razie upadku podstawy prawnej dla przetwarzania tych danych, np. rezygnacji z członkostwa w portalu społecznościowych czy właśnie śmierci użytkownika. Obrany kierunek regulacji jest dobry, chociaż przeszkodą może być egzekwowanie tych obowiązków od największych i najważniejszych amerykańskich spółek, przede wszystkim Facebooka.

47 W. Dubois, M. Daćków, Prawo..., s. 177.

48 Por. K. Veale, Online Memorialisation: The Web As A Collective Memorial Landscape For Remembering The Dead, http://three.fibreculturejournal.org/fcj-014-online-memorialisation-the-web-as-a-collective-memorial-landscapefor-remembering-the-dead, dostęp: 27.06.2017 r. Autorka przekonywająco udowadnia, że Internet realizuje już najważniejsze funkcje żałoby i upamiętniania zmarłych.

49 Wystarczy spojrzeć na listę najpopularniejszych haseł na Facebooku w 2015 r., żeby zdać sobie sprawę, jak łatwo zdobyć dostęp do cudzego konta: http://www.iflscience.com/technology/25-most-popular-passwords-2015/all, dostęp: 27.06.2017 r.

50 https:/www.statista.com/statistics/264810/number-of-monthly-active-facebook-users-worldwide, dostęp: 27.06.2017 r.

51 http://www.theloop.ca/dead-facebook-users-will-soon-outnumber-the-living, dostęp: 27.06.2017 r.

52 Konto na Facebooku ze statusem In memoriam.

53 D. Sperling, Posthumous..., s. 45.

54 W. Herzog (reż.), Lo i stato się. Zaduma nad światem w sieci, $2016 \mathrm{r}$.

55 Por. decyzja Generalnego Inspektora Ochrony Danych Osobowych nr DOLiS/DEC-520/12/35884, 35886, z 11.06.2012 r.

56 W. Dubois, M. Daćków, Prawo..., s. 178.

57 W. Dubois, M. Daćków, Prawo..., s. 182. 
spostrzeżenia odnotowuje Łukasz Goździaszek ${ }^{58}$. Według niego nie jest oczywiste, że interes osoby zmarłej jest ograniczony do likwidacji konta. Rozważmy sytuację, gdy znajdują się na nim utwory osoby zmarłej. Czy zniszczenie wszelkich informacji, wraz $\mathrm{z}$ utworami, nie narusza interesów (nieżyjącego już) autora?

Potrzeba ochrony danych osobowych osoby post mortem wraz z rozwojem technologii wzrasta. Widoczny jest niedobór środków legislacyjnych. Dziwi jednak, że doktryna nie wykorzystuje w analogii przepisów o prawie autorskim lub ochronie informacji medycznej po śmierci pacjenta. W związku z rosnącą wartością majątkową danych w internecie niektórzy autorzy analizują konstrukcje spadków cyfrowych ${ }^{59}$.

\section{Obecność interesów post mortem w ustawie z 16.10.1992 r. o orderach i odznaczeniach ${ }^{60}$}

Obszarem prawa, w którym są uwzględnione interesy osoby post mortem, jest prawo o orderach i odznaczeniach. Kwestii związanych z pośmiertnym przyznawaniem lub odbieraniem obywatelstwa czy nagród D. Sperling nie porusza w ogóle. Wynika to z medycznego ukierunkowania zainteresowań autora. Jednak wobec powszechności tych praktyk należy je zbadać. Uczynił to J. Mazurkiewicz. W jednym z artykułów konstatuje, że ordery i wyróżnienia państwowe stanowią dobro osobiste ${ }^{61}$. Przesłanki ich nadania wynikają z indywidualnych czynów. Osoba zostaje wyróżniona na podstawie własnych zasług, każde odznaczenie jest jednostkowe (zob. D. Sperlinga warunek identyfikowalności podmiotu ludzkiego z osobą, która już nie istnieje). Przez wzgląd na relację osoby z nagrodą J. Mazurkiewicz uznaje ordery i odznaczenia za dobra osobiste. Łączy je także z czcią jako dobrem osobistym, twierdząc ${ }^{62}$ że ordery stanowią jej zewnętrzny wyraz.

Wiele spraw wiąże się z przyznawaniem i odbieraniem orderów, nadawaniem lub odbieraniem obywatelstwa ${ }^{63}$. Postawmy więc pytanie: dlaczego? Czyj interes jest przedmiotem zainteresowania ustawodawcy? Pośmiertne zarządzanie odznaczeniami ma m.in. wymiar polityczny, ponieważ służy realizowaniu tzw. polityki historycznej. To jednak nie wyczerpuje odpowiedzi. Działania te bezpośrednio wpływają bowiem na dobrobyt osoby już nieżyjącej, ze względu na bilans interesów związanych z czcią osoby. Dlatego też pośmiertne uhonorowanie jest nagrodą dla zmarłego, a czyn przeciwny - karą. Rozliczenie z przeszłością, stanowiące tu motywację, zakłada nawiązanie relacji z osobą już nieżyjącą.

Według J. Mazurkiewicza w tych przypadkach prawo oddziałuje na dobra osobiste zmarłego; w teorii D. Sperlinga - na jego istnienie symboliczne.

\section{Status zwłok w prawie i jego konsekwencje dla ochrony interesów zmarłego}

Odpowiedzi na pytanie, czy zwłoki stanowią rzecz, D. Sperling poświęca jeden rozdział w książce. Kwestię tę porusza również analizując orzeczenia sądowe. Zwłoki stanowią

58 Ł. Goździaszek, Likwidacja tożsamości na portalu społecznościowym, w: J. Gołaczyński et al. (red.), Non omnis..., s. 305.

59 P. Szulewski, Śmierć 2.0 - problematyka dóbr cyfrowych post mortem, w: J. Gołaczyński et al. (red.), Non omnis..., s. 732.

60 Tekst jedn.: Dz. U. z 2019 r. poz. 25.

61 J. Mazurkiewicz, Czy dobra..., s. 426.

62 J. Mazurkiewicz, Czy dobra ..., s. 429.

63 W przeszłości w Polsce zdarzyły się precedensy odebrania orderów. W 1990 r. order Virtuti Militari odebrano Leonidowi Breżniewowi, a w 1995 r. taki sam order odebrano Iwanowi Sierowowi. 
pozostałość po zmarłym. Uprzedmiotowienie zwłok może nie tylko niweczyć interes osoby zmarłej, ale także negatywnie wpływać na społecznośćc4.

W polskiej doktrynie przeważa opinia, zgodnie z którą zwłoki stanowią rzecz ${ }^{65}$. Są, co prawda, rzeczą szczególną, res extra commercium, która nie może być przedmiotem obrotu gospodarczego. Ustawa o cmentarzach i chowaniu zmarłych rozróżnia zwłoki i szczątki ${ }^{66}$. Zwłokami są ciała osób zmarłych, a szczątkami: 1) popioły otrzymane przez spalenie zwłok; 2) noworodki martwo urodzone, płody i noworodki niezdolne do życia, które nie przeżyły okresu 24 godzin; 3) pozostałości zwłok wydobyte przy kopaniu grobu lub innych okolicznościach; 4) części ciała ludzkiego odłączone od całości ${ }^{67}$. Rudnicki podkreśla, że rozróżnienie to nie ma wpływu na zakres ochrony realizowanej dostępnymi środkami. W tym aspekcie interesy osób zmarłych są dobrze chronione, chociażby ze względu na gwarancję pochówku niezależnie od tego, w jakim stanie są zwłoki. Co do części ciała, których odłączenie następuje w sposób naturalny i które ulegają regeneracji (włosy, paznokcie itd.), to w doktrynie przeważa opinia, która dopuszcza je do obrotu gospodarczego ${ }^{68}$.

D. Sperling krytykuje angażowanie prawa własności w ochronę interesów zmarłego. Uważa, że kwestia zwłok jako przedmiotu własności jest sporna, a więc prawnie nieefektywna $^{69}$. D. Sperling przytacza interesującą teorię przedmiotu prawa własności Jamesa E. Pennera ${ }^{70}$. Według J. Pennera przedmiotem własności może być tylko rzecz, która da się oddzielić (separable) i jest odrębna (distinct) od właściciela. Właściciel musi być w stanie wykazać, dlaczego dana rzecz należy do niego, skoro może należeć do kogoś innego. Chodzi więc o zdolność właściciela do wskazania kauzy, dzięki której nabył własność. Następny warunek polega na tym, że w relacji właściciela do przedmiotu, właściciel może ulec zmianie, bez wpływu na (prawną?) jakość relacji. D. Sperling konkluduje, że na gruncie tej teorii ciało nie może być przedmiotem własności ze względu na jego nierozerwalny związek z osobą (uważa, że osoba i ciało pozostają w relacji konstytucji). Nie ma jednak przeszkód, za przedmiot własności uznać włosy, paznokcie czy krew.

Czy możliwe jest podążenie za sugestią D. Sperlinga i odrzucenie zastosowania konstrukcji prawa rzeczowego do zwłok? Uczynić to można w analogii do regulacji związanych z organami, które konsekwentnie nie są uznawane za rzeczy, choć niekiedy stosuje się do nich pojęcia z zakresu prawa rzeczowego. Ujęcie zwłok w podobny sposób wydaje się słusznym rozwiązaniem.

\section{Zakończenie}

W niniejszym artykule przekonywaliśmy, że śmierć organizmu ludzkiego nie implikuje zgaśnięcia interesów człowieka, a więc że śmierć nie niweczy jego istnienia jako podmiotu interesów. Jednakże prawa podmiotowe - interesy podmiotu uznane przez

\footnotetext{
${ }^{64}$ Zbadani studenci I roku medycyny twierdzili, że w celu oswojenia się z kontaktem ze zwłokami na zajęciach anatomicznych wykorzystywali posiadane na własność kości i czaszki m.in. jako dekoracje czy naczynia na orzeszki. Por. M. Bryś, M. Rydz, J. Karbowski, Doświadczenie śmierci u studentów Akademii Medycznej na zajęciach prosektoryjnych, w: J. Kolbuszewski (red.), Problemy Wspótczesnej Tanatologii, t. IV, Wrocław 2000, s. 453.

65 T. Gardocka, Czy zwtoki..., s. 268.

66 J. Rudnicki, Prawo do grobu: zagadnienia cywilistyczne, Kraków 1999, s. 30.

${ }_{67}$ Por. $\$ 8$ ust. 1 pkt 3 rozporządzenia Ministra Zdrowia z 7.12.2001 r. w sprawie postępowania ze zwłokami i szczątkami ludzkimi (Dz. U. Nr 153, poz. 1783 ze zm.).

68 E. Skowrońska-Bocian, w: K. Pietrzykowski, Kodeks cywilny..., s. 264.

69 D. Sperling, Posthumous..., s. 141-142.

70 D. Sperling, Posthumous..., s. 123.
} 
prawo i prawem chronione - stanowią atrybut osoby. Pojęcie osoby nie ma zaś zastosowania w kontekstach post mortem. Zarysowując problematykę ochrony interesów pośmiertnych w prawie polskim, posłużyliśmy się koncepcją podmiotu ludzkiego, zaproponowaną przez D. Sperlinga. Sperling zauważa, że trwanie interesów podmiotowych rozciąga się w czasie poza granicę życia osobowego. Interesy, których podmiotem jest osoba, są dzierżone przez podmiot ludzki. Podmiot ludzki dzierży interesy osoby także pośmiertnie, jeżeli identyfikowany jest z osobą, która istniała w przeszłości. Pojęcie to, reprezentujące każdego z nas w dyskursie normatywnym, zostało ugruntowane w języku podobnie jak termin „osoba” - oddając relacje, w jakich pozostajemy wobec wspólnoty ludzkiej lub jej członków. Jest więc pojęciem o treści aksjologicznej.

W prawie polskim obowiązują przepisy gwarantujące realizację interesów obiektywnych, gdy podmiot sam nie może o nie zabiegać (przykładem jest zgoda na zabieg operacyjny). Obecne są też uregulowania dotyczące bezpośrednio sfery post mortem (prawa autorskie, prawo o orderach i odznaczeniach i in.). Mimo to polska doktryna w większości sprzeciwia się uznaniu podmiotowej ochrony interesów zmarłych, powołując się przy tym m.in. na trudności związane ze wskazaniem podmiotu ochrony ${ }^{71}$. W artykule podjęliśmy polemikę z dominującym w polskiej doktrynie stanowiskiem, wskazując teoretycznoprawne podstawy uznania i podmiotowej ochrony interesów zmarłych oraz ich filozoficzne umotywowanie, m.in. w ramach Sperlinga koncepcji podmiotu ludzkiego.

\title{
Rights - Person - Death. Part II: Daniel Sperling's Theory and the Polish Legal System
}

\begin{abstract}
This article is divided into two parts. In the first part, which was published in 2018, we presented arguments in support of the concept of posthumous interests. Posthumous interests are understood as events that constitute a benefit or a harm to the deceased person, who no longer exists. A right is the interest of a person, which is recognized and protected by law. In the second part, we examine the possibility of applying the theory of posthumous interests in the Polish legal system. We address the following issues: medical confidentiality, protection of medical data after the death of a patient, author's moral rights, protection of the memory of the deceased, the law on orders and decorations, and the legal status of human corpses. The theoretical background for this article was the book by Daniel Sperling Posthumous Interest, in which the author outlined the problem in point from the perspective of the common law regime.
\end{abstract}

Keywords: death, person, interests of the deceased, human being, protection of the memory of the deceased

71 Przez ochronę podmiotu rozumie się ochronę przysługującą ze względu na indywidualne interesy konkretnej osoby zmarłej. W doktrynie pojawiały się poglądy zmierzające do uwzględnienia interesów osób zmarłych. Przykładowo Agnieszka Wedeł-Domaradzka dostrzega taką potrzebę, choć podstawy dla udzielenia ochrony poszukuje w prawach człowieka. Wpisuje się w tym w nurt, który nie dąży do uznania podmiotowości zmarłych, ale zapewnienia im ochrony ze względu na pewne kryteria ogólne, co było krytykowane w artykule. Por. A. Wedeł-Domaradzka, Śmierć a prawa człowieka, Toruń 2010, s. 320. 


\section{BIBLIOGRAFIA / REFERENCES:}

Boratyńska, M., Konieczniak, P. (2001). Prawa pacjenta. Warszawa: Difin.

Bryś, M., Karbowski, J., Rydz, M. (2000). Doświadczenie śmierci u studentów Akademii Medycznej na zajęciach prosektoryjnych. In J. Kolbuszewski (Ed.), Problemy Wspótczesnej Tanatologii, $t$. $I V$. Wrocław: Wrocławskie Towarzystwo Naukowe.

Czub, K. (2015). Dobra i prawa osobiste twórcy (na podstawie kodeksu cywilnego, prawa autorskiego i prawa własności przemysłowej). In J. Gołaczyński et al. (red.), Non omnis moriar. Osobiste $i$ majątkowe aspekty prawne śmierci czlowieka. Zagadnienia wybrane. Wrocław: Oficyna Prawnicza.

Daćków, M., Dubois, W. (2015). Prawo do bycia zapomnianym w internecie - za życia i po śmierci? In J. Gołaczyński et al. (red.), Non omnis moriar. Osobiste i majątkowe aspekty prawne śmierci człowieka. Zagadnienia wybrane. Wrocław: Oficyna Prawnicza.

Gardocka, T. (2015). Czy zwłoki ludzkie są rzeczą i co z tego wynika? In J. Gołaczyński et al. (red.), Non omnis moriar. Osobiste i majątkowe aspekty prawne śmierci człowieka. Zagadnienia wybrane. Wrocław: Oficyna Prawnicza.

Goździaszek, Ł. (2015). Likwidacja tożsamości na portalu społecznościowym. In J. Gołaczyński et al. (red.), Non omnis moriar. Osobiste i majątkowe aspekty prawne śmierci człowieka. Zagadnienia wybrane. Wrocław: Oficyna Prawnicza.

Hau, M., Jędrczak, S. (2018). Prawo - osoba - śmierć. Część I: Wokół koncepcji Daniela Sperlinga. Archiwum Filozofii Prawa i Filozofii Społecznej 17/2, s. 75-89.

Longchamps de Bérier, R. (1911). Studya nad istota osoby prawniczej. Lwów: Jakubowski.

Mazurkiewicz, J. (2012). Czy dobra osobiste mogą powstać po śmierci? In J. Balcarczyk (Ed.), Dobra osobiste w XXI wieku. Nowe wartości, zasady, technologie. Warszawa: LexisNexis.

Mazurkiewicz, J. (2010). Non omnis moriar. Ochrona dóbr osobistych zmarlego w prawie polskim. Wrocław: Prawnicza i Ekonomiczna Biblioteka Cyfrowa.

Rudnicki, J. (1999). Prawo do grobu: zagadnienia cywilistyczne. Kraków: Kantor Wydawniczy Zakamycze.

Sperling, D. (2008). Posthumous Interests. Cambridge: Cambridge University Press.

Szulewski, P. (2015). Śmierć 2.0 - problematyka dóbr cyfrowych post mortem. In J. Gołaczyński et al. (red.), Non omnis moriar. Osobiste i majatkowe aspekty prawne śmierci czlowieka. Zagadnienia wybrane. Wrocław: Oficyna Prawnicza.

Veale, K. (2017). FCJ-014 Online Memorialisation: The Web As A Collective Memorial Landscape For Remembering The Dead. The Fibreculture Journal 3, http://three.fibreculturejournal.org/ [last access: 27.06.2017].

Wedeł-Domaradzka, A. (2010). Śmierć a prawa człowieka. Toruń: Wydawnictwo Naukowe GRADO. 